\title{
The Function of Prophetic Forthtelling in Roho Christianity
}

\author{
Richard Mutura Bariu (PhD) \\ Pan Africa Christian University, Kenya \\ Research Associate, Stellenbosch University, South Africa
}

Doi: 10.19044/esj.2017.v13n35p146 URL:http://dx.doi.org/10.19044/esj.2017.v13n35p146

\begin{abstract}
This paper examines the forms and function of prophecy in Roho (Spirit-led) Christianity in Africa. It seeks to situate this function within the rubric of biblical prophecy. It takes seriously their beliefs and theological reasoning that informs their practice. We look at forms of biblical prophecy that generally serve as their guiding principle, namely: foretelling and forthtelling. The literature available on Roho Christianity largely focuses on the historical, sociological, and anthropological aspects of this brand of Christianity. Majority of scholars have paid attention to their origins, rituals, and interaction with the larger society. While this is important, there is very little attention given to one of their principal characteristics--an active prophetic ministry. This paper seeks to satisfy the following seven objectives. Firstly, we look at the prophetic role of the church in African society. Secondly, we try to establish the nexus between prophecy and salvation in Roho Christianity. Thirdly, we look at the forthtelling character and function of Jewish prophecy. Fourthly, we look at prophecy as a community constitution in Roho churches. Fifthly, we assess how prophecy acts as group ritual for identity maintenance. Sixthly, we examine ways in which prophecy acts as symbolic Christian ethics. Finally, we explore how prophetic forthtelling enhances socioeconomic support among Roho churches. In order to achieve the foregoing, we look at concepts common to Roho Christianity in an attempt to draw conclusions about the concept and nature of prophecy in Roho churches and convictions connected with them.
\end{abstract}

Keywords: Roho Christianity, Prophecy, Ethics, African society, Forthtelling, Foretelling

\section{Introduction}

The literature regarding Roho churches hardly deals with the function of prophetic forthtelling. The bulk of literature has so far dealt with 
historical, sociological, and anthropological themes regarding the said churches especially their origin, their interaction with society, their unique rituals and how they deal with diseases, though often times from a point of special theological interest (Höschele, 2008, p.41). Universally, the Church maintains that it has an active prophetic ministry. This prophetic ministry deals with some aspects of foretelling though it largely deals with the forthtelling aspect of prophecy.

On the one hand, prophetic foretelling predicts what would happen in the future based on present actions. It also focuses on predictions of what would happen or not happen if what is already revealed is not adequately adhered to. On the other hand, prophetic forthtelling names and condemns social evils and injustices committed by the members of the community of faith. Sometimes, it also names and shames acts committed by non-members after which members denounce the evils seeking forgiveness through repentance on their personal behalf and that of others. In biblical prophecy, forthtelling concerns itself with any behavior, action, practice or endeavor that in itself becomes a threat or poses a threat to the community of faith. The main aim of forthtelling is to ensure compliance with socially and spiritually acceptable traits while at the same time reducing the socially and spiritually unacceptable traits among the communities of faith. It further names and shames behaviors or actions deemed unacceptable among the community of faith and it is a threat to the eternal destiny of the entire community of faith. Thus, the aim of the exercise is to rid the community of anything that would hinder adherents from attaining the foretold future.

The Roman Catholic Church, for instance, affirming the primacy of prophetic forthtelling argues that "the Church must continue to echo her prophetic role and be the voice of the voiceless" (Ecclesia in Africa, article 70 quoting Populorum Progression, p.281). In the same article, it states that "the Church must denounce and combat all that degrades and destroys the person." In a separate Encyclical letter by John Paul, the Church asserts that:

The condemnation of evils and injustices is also part of that ministry of evangelization in the social field which is an aspect of the Church's prophetic role. But it should be made clear that proclamation is always more important than condemnation and the later cannot ignore the former, which gives it true solidity and the force of higher motivation (Sollicitudo Rei Socalis, p.572).

In this regard, prophesy as practiced among the Roho churches is not without precedence. It is understandably not academic. It serves these religious movements in the way they interpret phenomena which is both historical and current with particular emphasis on how various phenomena impact their lives individually and as communities of faith. Prophecy in Roho Christianity is functional and practical and it deals with issues 
affecting faith communities that include, but is not limited to, issues such as identity, ethos, ethics, healing, salvation, and social support.

\section{Prophetic Role of the Church in the African Society}

The church in the African society is increasingly redefining its boundaries in social engagement. The thick line that once existed separating the spiritual from the secular, which allowed for a dualistic view of the world, is constantly being perforated in order to allow for a view of a world that is monistic. In a monistic world, the spiritual and the secular interact seamlessly within the same world. Activities in the spiritual affect what happens in the secular world. What happens in the secular world also becomes a reflection of what is happening in the spirit world. Thus, by observing what is happening in the visible world, one can easily understand what is happening in the spiritual. By observing the physical world, one is able to know whether or not God is happy. Atonement and forgiveness of sins is therefore done in concrete terms, which makes it possible to know when God is pleased with people or not. This monistic view of the world accounts for prophetic forthtelling that the AIC's are constantly involved in. In fact, as we shall demonstrate elsewhere in this paper, this is the view found in the world of the Scriptures.

Archbishop Njeru Wambugu, the General Secretary of the Organization of African Instituted Churches (OAIC) and head of the National Independent Church of Africa, argues that the Church has a prophetic role that touches on the concrete world. However, such a claim demonstrates the close interaction of the spiritual and the physical world. He encourages his audience that:

If, for example, the government goes wrong, who will speak out against it on behalf of the people? Let them read in the Old Testament, which they like very much. Who was God using? It was his own prophets, whom he sent to the kings to tell them: "Your days are gone. You are making a mistake here. You are doing wrong there." When is the church going to wake up and realize that they have to stick out and challenge the leadership? When I am driving on this road and it has potholes, is it now politics if I say that the road has potholes? If the water we are drinking is dirty, is it politics to fight against that? Somebody somewhere must be responsible for the dirty water. God has given us his riches and we must be stewards of those riches. If God has given leadership to a president, to look after Kenya, he should make sure that every Kenyan enjoys his life and his protection here. If a leader does not secure that, he is not a leader. Those that are members of 
OAIC already know the importance of getting involved in politics... I am waiting for a time when church leaders will begin to even talk economics. Because the farmers whose price of produce is reduced by WTO, these farmers are members of a church and so the church is affected. People have to understand: if you are talking of poverty, you must ask where the poverty began and how it can be fought. If there are structures that make people poor, can we destroy them? If people say that they have no money to donate to the church, you have to ask, why they have no money. If around Kisumu, many people were living on cotton, and cotton went down so much, why was it so? You begin to ask pertinent questions about the causes of our poverty which leads to confronting it instead of lamenting (Kuhn, 2007, p.56).

One of the Bishops who attended the $2^{\text {nd }}$ Special Assembly of Africa of the Synod of Bishops, on October $10^{\text {th }}$, 2009, however, warns that:

The diversity of the challenges faced by many Catholic communities makes it difficult to list all the different prophetic roles that the Church must try to fulfill on the Continent of Africa today. The prophetic witness of those living in North Africa is different from those who live in sub Saharan Africa. The differences and challenges in sub Saharan Africa are also quite significant depending on whether one is speaking of East, West or Southern Africa.

In the same vein, he further argues that:

Africa is a continent of great variety and diversity of situations of both Church and Society. We must be cautious about generalizations both in the diagnosis of problems and issues and in the suggestion of solutions. The local particular Churches must take responsibility for their own concrete existence addressing situations that call for a prophetic response according to local circumstances $\left(2^{\text {nd }}\right.$ Special Assembly of African Synod of Bishops, 2009, p.1).

The import of this Bishop's warning and advice is that the Spirit's activities are not necessarily universal, rather they are contextual. Each church ought to hear the Spirit in light of their particular challenges and respond appropriately. He, therefore, implicitly acknowledges the existence and the primacy of prophetic witnesses in Africa today. Witnesses are not just pre-occupied with foretelling, but a prophetic forthtelling for a better society and nation. This is illustrated by this testimony about an Archbishop of Monrovia, in Liberia. 
Archbishop Michael Francis has courageously spoken out against one dictator after another in this small West African Republic as it descended into chaos and disorder. He truly became the "voice of the voiceless" the only one listened to as he denounced each atrocity without fear. Then as peace came to the country, he was struck down by a stroke and remains to this day, almost completely paralysed. The Liberian President, Ellen Johnson Sirleaf, described him when speaking in the cathedral in Monrovia, on the occasion to mark the Centenary of the establishment of the Catholic Church in Liberia, as "the voice of the nation". A voice that was silenced through ill health and which never hesitated to speak out forcefully against dictators and abusers of human rights of the people of Liberia $\left(2^{\text {nd }}\right.$ Special Assembly of African Synod of Bishops, 2009, p.3).

Consequently, this testimony underscores the fact that national political leaders are acknowledging that there is something the church is doing that is uncommon and beneficial to the society. However, some prophets are using their gifts for profit. They extort their followers who have to pay for every personal prophecy. In fact, they have become 'gospoprenuers' who are after money. In Zimbabwe, just like it is in many other African nations, there are many young prophets, largely operating in urban centers, who have transformed the religious landscape in a fundamental way (Chitando, Gunda \& Kügler, 2013).

\section{Prophecy and Salvation in Roho Christianity}

Salvation in African Roho Christianity is not limited to the salvific act of Jesus Christ dying on the cross. It surpasses the forgiveness that one experiences after encountering Christ the savior. Salvation is experienced every Sunday after either personal prophetic testimonies or a session dedicated to prophetic forthtelling that makes the culprits own up crimes they had committed without much regard on whether they would be apprehended or not. Sinners repent and experience freedom from guilt and resentment. The offended also experience salvation or freedom from hate and vendetta. For example, Sr. Geneviève Uwamariya, a Rwadese who most of her family members were massacred during the 1994 Tutsi-led genocide in Rwanda, on $27^{\text {th }}$ August 1997, listened to personal prophetic testimonies that changed her life. These testimonies were by a group of women who prepared the genocide detainees for the Jubilee year of 2000. The message was simple "If you have killed, you must ask pardon of the surviving victims; with this you will be freed from the burden of vendetta, of hate and 
resentment. If you are a victim, you are obliged to offer your forgiveness to the person who has wronged you, so you will allow him to be free of the burden of his crime and the evil that is in him" (USG/SEDOS meeting, 10/10/2009 proceedings).

Uwamariya while in the meeting concedes that one person hearing this "stood up in tears, fell on his knees before me and begged me saying in a loud voice: "Mercy"... He admitted that it was he who killed my father and described in detail the death of my loved ones." This confession touched Uwamariya's life so significantly that besides the first reaction of shock, she froze on the spot on recognizing that the person who killed her family members was a close family friend with whom they grew up and shared everything in common.

Given the prophetic context where the confessions were taking place, Uwamariya, instead of being overwhelmed by hate and revenge, she was gripped by pity and compassion. As a result, she says, "I lifted him up, I embraced him, and sobbing I told him, you are and will always be my brother." Uwamariya confesses that "at that moment, I felt as if a weight had been lifted from me. I found again interior peace and I thanked the person who was still in my arms. To my great surprise, I heard him shout 'Justice can follow its course and condemn me to death, now I am free!"’

Such a forthtelling experience not only brings freedom to the community members, but also socializes the community to own evils committed by confronting what would otherwise slow them down or tear them down. Experiences such as these within the communities of faith enhances members' belief in God the savior who out of love sends his prophets to speak out against social evils that if not addressed would attract God's wrath.

\section{Forthtelling Character and Function of Jewish Prophecy}

Prophecy in the Bible deals with concrete life-related issues affecting the communities of faith. Prophecy is neither abstract nor theoretical; it is concrete, dealing with challenges threatening obedience to God by ordinary people. Biblical prophecy is both foretelling and forthtelling in nature. Let us consider the following examples from scripture:

The Lamentations of Jeremiah address social issues facing the community of faith in his day. In one instance, Jeremiah says:

Let us examine our ways and test them, let us return to the Lord. Let us lift our hearts and our hands to God in heaven, and say: we have sinned and rebelled against the Lord and you have not forgiven (3:4042).

Jeremiah further confronts the social evils in a formulaic prophetic fashion: 
Come out of her, my people!

Run for your lives!

Run from fierce anger of the Lord (51:45) ...

We are disgraced, for we have been insulted

and shame covers our faces,

because foreigners have entered the holy places of the Lord's house.

But days are coming declares the Lord,

when I will punish her idols,

and throughout her land

the wounded will groan (Jer. 51:51-52).

This prophecy addresses the current state of affairs and narrates to the Israelites, the community of faith, sins committed by Babylon against them. It is both advisory and promissory to the people of faith. It spells out what will happen to the offenders as a consequence of present actions.

Prophet Amos prophetically names and shames the crimes that were happening among the people of faith. He writes:

This is what the Lord says, "For three sins of Israel, even four, I will not turn back my wrath. They sell the righteous for silver, and the needy for a pair of sandals. They trample on the heads of the poor as upon the dust of the ground and deny justice to the oppressed. Father and son use the same girl and so profane my holy name. They lie down besides every altar on garments taken in pledge. In the house of God they take wine taken as fines" (Amos 2:6-8).

Amos further confronts the social evils committed by those outside the community of faith. He declared prophetically what God would do as a result. He writes:

This is what the Lord says, "For three sins of Moab, even four, I will not back my wrath. Because he burned as if to lime, the bones of Edom's king, I will send fire upon Moab that will consume the fortresses of Kerioth. Moab will go down in great tumult amid war cries and the blast of the trumpet. I will destroy her ruler and all her officials with him." (2: 1-3).

Concerning Judah, Amos prophesies:

This is what the Lord says: "For three sins of Judah, even four, I will not turn back my wrath. Because they have rejected the law of the Lord and have not kept his decree, because they have been led astray by false gods, the gods their ancestors followed, I will send fire upon Judah that will consume the fortresses of Jerusalem (Amos 2: 4-5).

Prophet Amos has similar formulaic forthtelling prophecies against other neighboring nations such as Tyre, Edom, Ammon, and towns such as Gaza and Damascus. 
From the foregoing, the nature and function of Hebrew prophecy is overt. It confronts and shames actions that compromise the communal good of all or amount to injustices against other people which consequently hinder the predicted future. Therefore, Hebrew prophecy is forthtelling in nature except for messianic prophecies and a few others that foretell the future. Prophecies in the Hebrew Bible largely address "specific social, political, and religious circumstances in ancient Israel and Judah" (McKenzie, 2005, p.67). In ancient Israel and Judah, prophetic foretelling is largely limited to the eschatological coming of the messiah. All other kinds of prophetic foretelling were either a reinterpretation of prophetic forthtelling with the addition or alternative of a reapplication of prophecies forth-told whose actions were futuristic. It would be erroneous for readers to typically interpret prophecy in the Bible as having its primary intent limited to the foretelling of the future.

\section{Prophecy as a Community Constitution}

Prophecy is a ritual that not only establishes a sense of connectedness to the divine, but also strengthens the fellowship of members through their common orientation towards God. At the same time, prophecy reinforces a sense of separation between worshippers and non-worshippers. Prophetic forthtelling may therefore be understood as contributing to the constitution of a community and as disassociation from the environment (Höschele, 2008, p.45).

In Roho Christianity, prophecy is closely and commonly tied to their identity and distinguishes their worship. Prophets at times employ unusual methods to emphasize why every member should obey each prophetic utterance. Some of the methods mark a shift in behavior, while others underscore a leading by the Spirit that evidently stresses this central identity mark which differentiates the members from non-members. Prophecy, thus, serves a constituting function among these communities because it is a means of advertising ways of accessing salvation, grace, and belonging.

Prophetic forthtelling as a religious practice further dissociates members from any environment that is deemed evil. It confronts any type of practice or behavior that if allowed to continue would lead to multiple identity among members or lead to non adherence to prophetic utterances which unite people under the same ethos. It eradicates any threat, be it spiritual, social or political, with an aim of restoring fellowship. It enables individuals to embrace communal ethos revealed through prophetic utterances. In so doing, it unavoidably demarcates the boundaries of their community and serves to unite a group of believers since it advocates for a common body of beliefs among the members. Sundkler, in his classic, Bantu 
Prophets, underscores the importance of distinct communal codes and argues that prophecy

is an experience common to all independent Bantu Churches that as communities they need distinct codes, which every member has to obey and follow... [E]very Church uses its own distinct formulae in worship... all these are rules which distinguish one's own particular Church and thereby integrate it as a group (Sundkler, 1961, p.163).

A notable example is one found in the biography of Isaiah Shembe, the founder of the amaNazaretha. Shembe was a healer and exorcised demons with the conviction that God directed him. In 1911, he broke with his church over the Sabbath issue and started the amaNazaretha, which means "Nazarites". Shembe declared that all verses in the Old Testament referring to Nazarites were to be applied to his followers as well (Sundkler, 1961, p.111). He saw it as a sign of detachment from the larger society and a sign of holiness (Höschele, 2008, p.46), on which all members coalesce.

In this regard, prophecy among the Roho Christianity is a sign of unity and universality. It can be encountered by believers and church leaders of several countries without reference to one another. It forms the body of knowledge and revelation that socializes all the members on the structure and character of communal worship. At the same time, it is a mark of catholicity. It cuts across all the churches as a distinctive feature.

Thus, prophetic forthtelling is viewed as divine intervention that is guided by the promises of God to enhance fellowship and therefore applies in the entire society. This is aimed at achieving membership and inclusiveness to all its adherents. It has tangible benefits to men, women, and children, thus, revitalizing the whole of humanity with regard to holiness.

In conclusion, prophecy possesses a uniting and a separating function. It is a religious practice that forms the body of knowledge that constitutes the community of faith. The separating function helps to determine who true worshippers are, while the uniting function underscores the central norm on which all members must subscribe-holiness. Prophecy further serves as a mark of apostolicity. The presence of prophecy in the churches becomes the overt indicator that the church and its teachings are in harmony with the Scripture, the prophets and in continuity with the teachings of the apostles.

\section{Prophecy as a Group Ritual for Identity Maintenance}

The Musanda Christian church of Kenya based in Kisumu views prophecy as so paramount that without it, the life and faith of the church would cease. For them, prophecy is primarily forthtelling and sometimes foretelling. For instance, the Holy Spirit through his appointees, whom he possesses and uses as a mouthpiece every Sunday, confronts any behavior or 
act that is contrary to the desire of the Spirit. Marko Kuhn rightly observed that when the drum was beaten, people spoke in other tongues and received prophecies (Kuhn, 2007, p.29). Anything that contradicts or demeans the expressed will of the Spirit jeopardizes the existence of the group. If such behavior is not addressed, the devil, evil spirits and other malevolent spirits would attack the church causing deaths, incurable sicknesses, and maladjusted behavior. To avoid such in the community of faith, prophecy has to confront anything and everything that threatens the identity of the group.

The worship service is replete with various rituals which act as identity markers. Every member is expected to exhibit similar characteristics except when there is unconfessed sin. During a prophetic session, people have to do certain things for the spirit to possess the leader and the people. For instance, during a session of prophetic forthtelling, people engage in rhythmic singing and prayer, which also involves rhythmic drumming in order to make the people to become possessed by the Holy Spirit so as to confirm and confess the sins they had committed, and already mentioned by the prophet. The Lord's Prayer is said three times as people kneel and stand, with occasional sitting and standing. This is followed by forgiveness of sins, which is declared by the prophet, after which the prophet closes the session in prayer.

Marko Kuhn, in an interview conducted in Musanda Christian church, observes that the

prophecies can be about the coming sicknesses of people, about problems that the country will face, when the rain will come or a famine, whether there will be wars in different parts of the world. All this will be revealed in the church, so that there will be no secrets and surprises any more. The Spirit also reveals sins that people have committed. These are also spelt out, so that they can be removed from the people who did those bad things (2007, p.29).

From Kuhn's observation, it is so clear that for this church, just like in all other churches within Roho Christianity, prophecy is both foretelling and forthtelling. The forthtelling aspect cleanses and prepares the believers to remain effective agents of Christ on earth and at the same time please the Spirit to spare non-members from calamity.

\section{Prophecy as Symbolic Christian Ethics}

Prophecy plays a pivotal role in determining belonging and separation. Both belonging and separation are made visible for many African Christians in concrete behavior (Höschele, 2008, p.47). Positively, prophecy becomes a "ritual communion and a shared persuasion" (Höschele, 2008, p.47). It guides on what is expected in order to belong as well as what would 
lead to separation. It helps in the identification and "rejection of certain welldefined activities viewed as the negative" so as to reinforce positive aspects of belonging.

Roho Christians view prophecy as a call to be ritually active; implying that God expects them to remain active in all matters of faith and conduct by adhering to all the prohibitions and prescriptions for ethical living in the society. Those outside of the community of faith can easily misconstrue prophecy as encouraging legalism or encouraging individuals to embrace extremes on spiritual, social and political matters. Such interpretation of the role of prophecy would only simplify the complex function of prophecy within Roho Christianity.

Rather than read legalism in the prescriptions and prohibitions, prophetic forthtelling has a soteriological and moralistic function in Roho Christianity. As a soteriological function, prophecy defines salvation as "a gift of God" that is never earned. It also views good works as "the result of salvation and not a means of salvation" (Mkiramweni, 1998, p.21-22). By so doing, it defines and affirms the religio-ethical traits of those who are deemed as saved. The moralistic function of prophecy defines and affirms behavior that is considered morally right. It proscribes and guards this behavior as an identity maintenance system.

In many African Instituted Churches, prophecy is realized in a radical way. Among Roho Israel Church of God in Kenya, prohibitions are taken so radically that even sexual intercourse is a taboo during worship days and the night before (Kuhn, 2001, appendix, 11). Jules-Rosette's observation regarding prophetic forthtelling among the Bapostolo of Zimbabwe tells:

Both with respect to their performance and on a personal basis, the semi-autonomous events of confession, curing, prophecy, instruction sessions, and palavers are linked to kerek [worship service]. It... also provides the background and model for another category of ritual events: baptism, funerals, and confirmations in high ecclesiastical office (1975, p.156).

In Roho Christian communities, specific prophetic prohibitions are not taken as burdensome, rather they are interpreted by the members as safety measures, which if "disrupted, the whole system can disintegrate" (Höschele, 2008, p.49). Therefore, prohibitions are religious taboos of which the breaking of them is deemed as a serious offense that is publicly and visibly embarrassing. Prophetic prescriptions in this regard form codices of behavior which are regarded as taboo spheres. In addition, they are enjoined with cultural considerations, already familiar to the audience and articulated in a practical way. This makes salvation and reception of grace and healing among the members a public phenomenon since it is practiced in the public 
sphere. Salvation is, thus, both personal and communal. Public manifestations of having experienced healing or salvation is a requirement that attests to authenticity of prophecy thus bringing honor to God. Needless to say, "Christian faith, the forgiving grace of God, and the strict adherence to... rules are a cultural necessity. Just as traditional taboos usually had a distinct function in the society concerned, such rules may be viewed as a concretization of faith and, thus, a dimension of inculturation" (Höschele, 2008, p.49).

\section{Prophetic Forthtelling and Socio-economic Support in Roho Christianity}

Prophecy is regarded as a mechanism of liberation for the oppressed and disenfranchised people. In Roho Christianity, "churches are bastions of survival and prophetic churches are networks of liberation" (Lincoln \& Mamiya, 1990, p.12). Prophecy is thus aimed at improving spiritual, economic and social conditions for its adherents. Sunday services and prophecies are geared towards improvement of the economic and social wellbeing of the followers. In addition, prophets promise a hope for afterlife with a spirituality that is grounded on concrete realities and attempts to selfimprovement. Temporal challenges are addressed in the light of spiritual realities, thus, making churches follow a prophetic stance in addressing social problems such as poverty, sickness, unemployment, and basic depravation.

Pastors and leaders inform members of social problems through sermons, church events, and, in some instances, political and social speakers from the community (Barnes, 2004, p.205). Prophetic services seek to alter one's personal life by instilling hope and courage in confronting the social problems and cultivating a desire and a willingness to affect social improvements (Barnes, 2004; Cavendish, 2001; Wilmore, 1994).

This prophetic orientation of Roho churches allows for social engagements with an aim of improving the social and economic wellbeing of the members. Therefore, each church

holds as its ultimate values (sic) communalism, the welfare of the populace, and integral relation of the spiritual and the material, and the moral obligation to pursue social-political concretization of the theological principles of equality, justice, and inclusiveness (Sawyer, 2001, p.67).

Cornel West argues that the basic obligation and contribution of prophetic Christianity toward social:

... is that every individual. . . should have the opportunity to fulfill his or her potentialities. This first and fundamental norm is the core of the prophetic Christian gospel. . . The fuller prophetic Christian 
tradition must thus insist upon both this-worldly liberation and other worldly salvation as the proper loci of Christianity. For prophetic Christianity, the two inseparable notions of freedom are existential freedom and social freedom. . . Existential freedom (i.e., salvation in the view of this author) empowers people to fight for social freedom (1982, p.16, 18).

Thus, freedom from anything that enslaves, be it social, spiritual, economic or political, comes to focus during prophetic services with the aim of enabling the members to overcome such evils. By confronting such evils, they strengthen the communal fabric and raise the consciousness of the immediate conditions they need to engage in for the attainment of liberation both physically and spiritually.

Most of the community outreach services have to do with social support services which spur a self-help tradition which socializes all the adherents within the Roho churches. These outreach services are spearheaded by prophets or priests with prophetic charisma to influence the adherents to obtain this as a way of life or a marker of their Christian membership.

\section{Conclusion}

Prophecy in the Bible and in Roho Christianity is largely forthtelling in nature and character. Prophecy is a ritual communion and a shared persuasion that primarily socializes, constitutes, and maintains the identity of the community of faith. It is used to create and maintain shared identities by providing the shared ethics among adherents and by further practically addressing concrete realities that affect the people of faith, especially the types that compromise their destiny collectively as well as individually. It provides the basis for ethical living within the community of faith as well as the backbone for socioeconomic support for members who are disadvantaged materially. Besides being closely patterned to Old Testament prophecy, it actively members those in faith communities, while dismembering those outside the faith communities being cognizant of African realities.

\section{References:}

1. Barnes, L. S. (2004). Priestly and prophetic influences on Black Church social services. Social Problems, 51 (2) 202-221.

2. Bennetta, J. (1975). African Apostles: Ritual and conversion in the Church of John Maranke. Ithaca: Cornell University Press.

3. Cavendish, J. (2001). To march or not to march: Clergy mobilization strategies and grassroots antidrug activism. In Sue S. Crawford and Laura R. Olson (Eds.) Christian clergy in American politics (Pp. 203-23). Baltimore, MD: The Johns Hopkins University Press. 
4. Chitando, E., Gunda, M. R., \& Kügler, J. (eds). (2013). Prophets, profits and the Bible in Zimbabwe. University of Bamberg Press.

5. Dillon-Malone, C. M. (1978). The Korsten basket makers: A study of the Masowe apostles - An indigenous African Religious Movement. Lusaka: Institute for African Studies.

6. Hastings, A. (1994). The church in Africa, 1450-1950. Oxford: Clarendon.

7. Höschele, S. (2008). On Sabbath keeping and Sabbath theology among younger African churches. Spes Christiana, (18-19)19-52.

8. Isichei, E. (1995). A history of Christianity in Africa. Grand Rapids: Eerdmans.

9. Lincoln, C. E. \& Mamiya, L. H. (1990). The black church in the African-American experience. Durham, NC: Duke University Press.

10. Marie-Louise, M. (1975). Kimbangu: An African prophet and his church. Oxford: Blackwell.

11. McKenzie, S. L. (2009). How to read the Bible: History, prophecy, literature, - why modern readers need to know the difference, and what it means to faith today. Oxford University Press.

12. Kuhn, M. (2001). "From African Consciousness to Sub-Conscious Inculturation: A Study into African Independent Churches (AICs) in Nyanza/Kenya." Diploma Thesis, University of Freiburg.

13. Kuhn, M. (2007). Prophetic Christianity in western Kenya: Political, cultural and theological aspects of African Independent Churches $(A I C s)$ Dokumentation der Leitfadeninterviews, Freiburg.

14. Mazambara, P. D. (1999). The self-understanding of African Instituted Churches: A study based on the church of apostles founded by John of Marange in Zimbabwe. Aachen: Mainz.

15. Mbiti, J. S. (2004). The role of the Jewish Bible in African Independent Churches. International review of mission, 93 (219237).

16. Mkiramweni, K. (1998). Worship among Seventh-Day Adventists. B.D. thesis, Makumira University College.

17. Moodley, E. J. (2004). "Shembe, ancestors, or Christ? A missiological inquiry into the status and role of Jesus Christ in the amaNazaretha church, Kwa-Zulu Natal, South Africa." Ph.D. diss., Asbury Theological Seminary.

18. Newcombe, S. \& Harvey, S. (eds). (2016). Prophecy in the new millennium: When prophecies persist. Routledge.

19. Nortey, J. J. (1989). Independent African Churches - are they genuinely Christian? Spectrum, 20 (2) 29-37.

20. Oosthuizen, G.C. (1967). The theology of a South African Messiah. Leiden: Brill. 
21. Ositelu, R. O. O. (2002). African Instituted Churches: Diversities, growth, gifts, spirituality and ecumenical understanding of African Initiated Churches. Münster: Lit.

22. Perrin Jassy, M. (1973). Basic community in the African Churches. Maryknoll: Orbis.

23. Sawyer, M. R. (2001). Theocratic, prophetic, and ecumenical: Political roles of African American clergy. In Sue S. Crawford and Laura R. Olson (Eds.) Christian clergy in American politics (pp. 6684). Baltimore, MD: The Johns Hopkins University Press.

24. Shorter, A. (1978). Recent developments in African Christian spirituality. In Edward Fasholé-Luke et al. (Eds.) Christianity in Independent Africa. (pp. 531-544). London, Rex Collings.

25. Sobol, R. (2002). Abayudaya: The Jews of Uganda. New York, NY: Abbeville.

26. Sundkler, B. (1961). Bantu prophets in South Africa. London, Oxford University Press.

27. Turner, H. W. (1967). "A tTypology for African rReligious mMovements." In Journal of rReligion in Africa 1 (1) 1-34.

28. Wilmore, G. S. (ed.) (1994). Black religion and black radicalism: An interpretation of the religious history of Afro-American people. New York, NY: Orbis Books. 